\title{
Preparation, Processing and Packaging of Pre-Mix for the Production of Carrot Dessert
}

\author{
GaziJunaidMansoor -AaqibKhursheed-Dr. Deeba S. Jairajpuri \\ Department of Food Technology \\ Faculty of Engineering and Interdisciplinary Sciences \\ Jamia Hamdard, Hamdard University, New Delhi-62
}

\begin{abstract}
Carrot Dessert (Indian: GajarKaHulwa) is the popular dehydrated carrot based product along with other ingredients like milk solids, sugar, coconut, dry fruits and ghee. The product has gained its importance because of its nutrition, health benefits, sweet taste and trends in some societies of consuming sweet foods after meals. The purpose of this research project was to develop a Ready to Cook (RTC) carrot desert which can satisfy the taste of common people while maintaining the regional and traditional integrity and which can create its own space in the market. During the project work, different recipes were made in which the ratio of ingredients carrot, milk solids, sugar, coconut and dry fruits ratio was varied. Four different recipes were prepared contained carrot, milk solids, sugar, coconut and dry fruits at the rate of $(15 \mathrm{~g}, 20 \mathrm{~g}, 30 \mathrm{~g}, 2 \mathrm{~g}, 5 \mathrm{~g}),(20 \mathrm{~g}, 30 \mathrm{~g}, 20 \mathrm{~g}, 2 \mathrm{~g}, 5 \mathrm{~g})$, $(30 \mathrm{~g}, 20 \mathrm{~g}, 40 \mathrm{~g}, 2.5 \mathrm{~g}, 5 \mathrm{~g}),(40 \mathrm{~g}, 15 \mathrm{~g}, 40 \mathrm{~g}, 2 \mathrm{~g}, 3 \mathrm{~g})$ respectively. A novel product was successfully produced and on the basis of cooking time, sensory scores and nutritional values the recipe containing the ingredients at the rate of $(30 \mathrm{~g}, 20 \mathrm{~g}, 40 \mathrm{~g}, 2.5 \mathrm{~g}, 5 \mathrm{~g})$ was considered best and which was then standardized and on which basis the package of net weight $160 \mathrm{~g}$ was formulated.
\end{abstract}

Keywords: Dehydrated carrot, Milk powder, Dry fruits, Nutritional value, Sensory characteristics Packaging.

\section{Introduction}

Increasing affluence and leisure are among the most pervasive trends in contemporary society. Affluence, a function of accelerating technology, and leisure, the by-product of emerging economic abundance, increasingly characterize the social environment within which the society's life style is given expression (Kruszelnicki K. S.). Machewad et al, (2003) studied the drying properties of carrots and their suitability for producing various value added products. Chemical properties of carrots indicated their suitability for drying and the feasibility of using carrot shreds for further processing. Leaching losses were observed in reducing sugars and total sugars during pre-treatments and an adverse effect was seen on beta-carotene content in all samples. Reconstitution ratio of dried carrot shreds was higher in pre-treated samples than untreated. Carrot shreds dried in open air had a lower reconstitution ratio. It was suggested that dried carrot shreds could be used as a base material for preparation of carrot halwa (halva).Basantpure et al, (2003) conducted experiments to develop dehydrated carrot halwa and studied the effect of milk to carrot ratio, sugar, sodium metabisulphite, and temperature on the quality of dehydrated halwa. Central composite rotatable design was used at five levels of independent variables. The results showed that the rehydration ratio decreased with an increase in milk to carrot ratio, sugar and sodium metabisulphite whereas, it increased with an increase in temperature. All these variables decreased the sensory responses namely, appearance, texture, flavour and overall acceptability at quadratic level. The interaction between milk to carrot ratio with sugar, sodium metabisuiphite and temperature, however, increased sensory responses. Sodium metabisulphite and temperature interaction also increased all the responses significantly. Based on individual and compromise optimization and canonical analysis, optimum conditions recommended were: milk to carrot ratio of 2, sugar $225 \mathrm{~g} / \mathrm{kg}$ of carrot shred, $255 \mathrm{ppm}$ sodium metabisulphite and drying air temperature of $71^{\circ} \mathrm{C}$

Pazarincevic and Baras, (1970) studied the trans beta-carotene content in fresh carrots, blanched fresh carrots and carrots dehydrated by different processes. After steam blanching for 5 min the carrots were dried by conventional air-drying at 60,70 and $80^{\circ} \mathrm{C}$, by vacuum drying at 60 and $70^{\circ} \mathrm{C}$ and vacuum drying at the same temperature after nitrogen purging. Results indicated major decrease in trans beta-carotene content after conventional air-drying, losses being more pronounced at lower temperature and longer drying periods. The losses of trans beta-carotene at 60,70 and $80^{\circ} \mathrm{C}$ was 48,40 and $38 \%$ in blanched carrots respectively. Only 21 $22 \%$ losses in vacuum drying, $7 \%$ with purging also have been reported. 
Grishin et al, (1973) studied the kinetics of dehydrating vegetables and changes in the main chemical constituents (ascorbic acid, carotenes, essential oils, total sugars) due to drying process. It was recommended that diced carrots (cubes 5-8 mm) should be dried at $160^{\circ} \mathrm{C}$. Carrots and onions were suggested to be used as basic ingredients of the snacks. Reyes et al, (2002) analyzed the drying curves for $3 \mathrm{~kg}$ batches of carrot dice $(9 \mathrm{x}$ $9 \times 3 \mathrm{~mm}$ ) in a mechanically agitated fluidized bed drier operated at temperature of $70-160^{\circ} \mathrm{C}$, air velocities of $1.1-2.2 \mathrm{~m} / \mathrm{s}$ and stirring rates of 30-70 rpm. Moisture content and shrinking of diced carrot pieces were determined. Drying kinetics were modelled by Fick's second law, for which an optimal agreement with the experimental data was obtained when the effective diffusivity was determined by a correlation based on air velocity, air temperature and the dimensional less moisture content of carrot dice. Loss of carotenes was minimum, when drying was carried out at about $130^{\circ} \mathrm{C}$ with a drying time below $12 \mathrm{~min}$.

\section{Materials and Methods}

The raw materials carrot (Daucuscarota), milk powder, sugar, coconut powder and dry fruits were procured from local market.

Preparation of pre-mix:Prior to recipe preparation the carrots were blanched at $85^{\circ} \mathrm{C}$ for $1.5 \mathrm{~min}$ in water bath (Precision Stainless Steel, Model 184), in a solution of $1 \%$ calcium chloride (E.NO. 509) which acted as a firming agent and $0.1 \%$ sodium meta bisulphate (E.No. 223) used as a preservative and an antioxidant and immediately after blanching, the carrots were soaked in distilled water which contained ice cubes $\left(0{ }^{\circ} \mathrm{C}\right.$ for 15 minutes) to stop further cooking. The above temperature, time and additives concluded that this treatment is best for the preservation of carotenoid content of carrots. The carrots were then dehydrated in Hot air Oven(Tempo Scientific And Laboratory Equipments India Pvt Ltd) at $60^{\circ} \mathrm{C}$ for $14-16$ hrs Fig. 2The carrots were then sliced and then crushed (Tempo Scientific and Laboratory Equipments India Pvt. Ltd.).

The ground carrots were then mixed with other ingredients including milk powder, ground sugar, coconut powder and dry fruits. During mixing four samples were prepared containing the ingredients ground carrots, milk powder, ground sugar, coconut powder and dry fruits in the ratio of $(15 \mathrm{~g}, 20 \mathrm{~g}, 30 \mathrm{~g}, 2 \mathrm{~g}, 5 \mathrm{~g}),(20 \mathrm{~g}$, $30 \mathrm{~g}, 20 \mathrm{~g}, 2 \mathrm{~g}, 5 \mathrm{~g}), \quad(30 \mathrm{~g}, 20 \mathrm{~g}, 40 \mathrm{~g}, 2.5 \mathrm{~g}, 5 \mathrm{~g}),(40 \mathrm{~g}, 15 \mathrm{~g}, 40 \mathrm{~g}, 2 \mathrm{~g}, 3 \mathrm{~g})$ respectively and the pre-mix was packed in air tight LDPE packaging materials, developed by R \& D of Kunwal Foods and Spices, Fig. 4, Fig. 5.

Preparation of carrot desertFor desert preparation the ratio of amount of water to the pre-mix was 3:1, the mixture was steamed for four whistles so that carrots are properly rehydrated and swollen. The ghee was used at the end to impart the characteristic yellow color.

Chemical characteristics Moisture, ash and fat content were determined according to AOAC 2000 methods. Protein content was determined as per (IS: 7219:1973): Kjeldhal Method, protein content was obtained by using the conversion factor of 6.25, Dietary fibre was determined by (IS: 11062) and carbohydrate content by difference method.

Sensory evaluationCooked Carrot dessert samples were evaluated for overall acceptability (colour, texture, aroma and taste) and was carried out as per 9 point Hedonic scale, by the help of ten semi trained judges.

Statistical analysis ANOVA - post hoc compariso- ns. The means were compared using Duncan's multiple range test (2007).

Microbial analysis Yeast, mold and Coliforms growth was checked. Analysis at different intervals of time was done at different temperatures for example; for yeasts and molds at $28^{\circ} \mathrm{C}$, for Coliforms at $36^{\circ} \mathrm{C}$.

\section{Results and Discussion}

Physio-chemical and microbial characteristicsThe proximate analysis revealed that the product developed was high in protein, carbohydrate as well as in fibre content, Table 2 . The $\mathrm{pH}$ was first decreased during first 15 days of storage but increased afterwards, but does not produce any undesirable change in the product, Fig.6. Permitted growth of yeasts, molds, Coliforms was found in all the samples at different intervals of time, Table 3.

Sensory CharacteristicsThe Sensory evaluation was carried out as per 9 point Hedonic scale, Table 4. The sensory attributes that were taken into consideration include: color, texture, aroma, taste, overall acceptability and rank. The values are the means of ten readings. Among the fourrecipes, the third recipe had highest overall acceptability, compared to the others. 
Figures

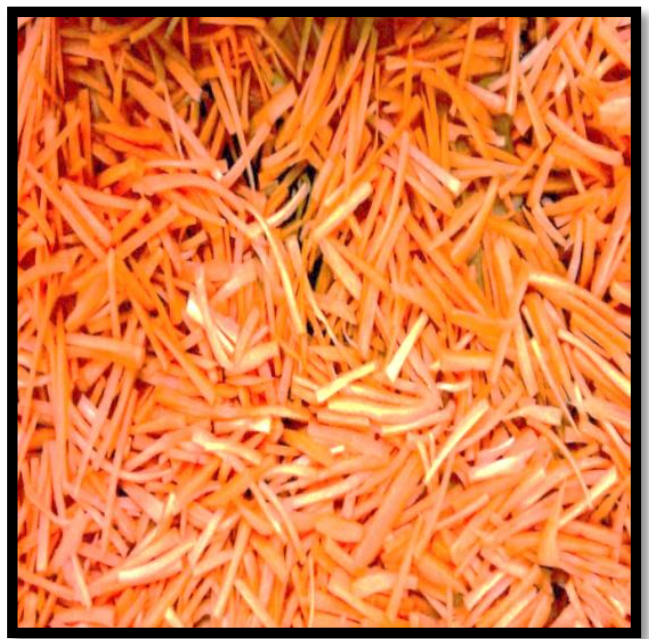

Fig. 1: Sliced Carrots

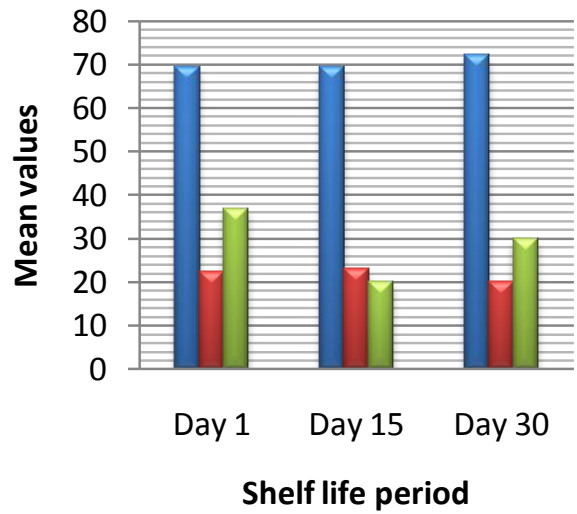

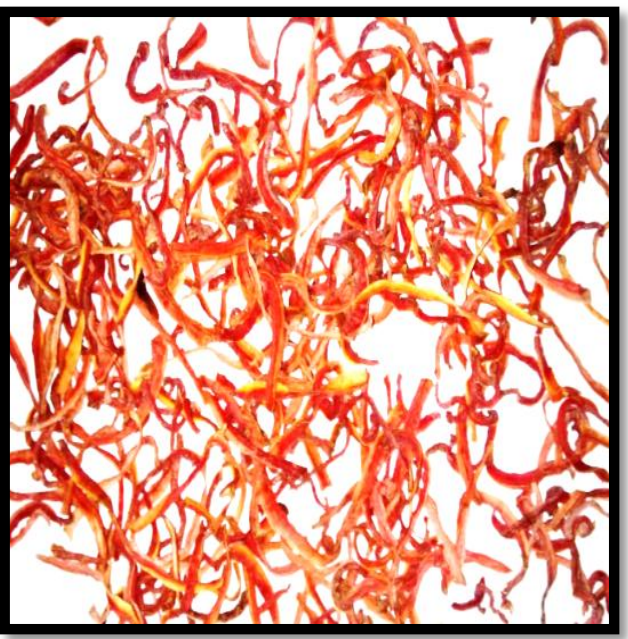

Fig. 2: Dehydrated Carrots

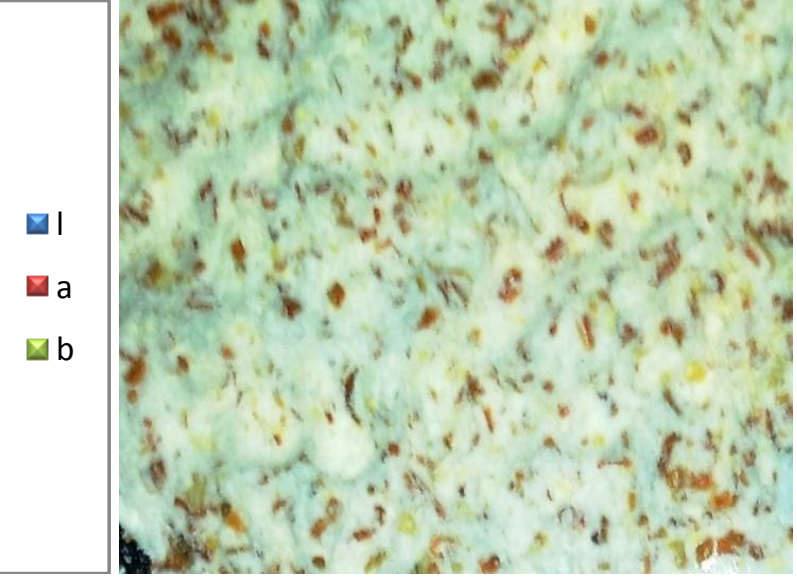

Fig. 3: Mean values of colour for the

Dried Carrot stored for Day 1, 15 and 30 (at $25^{\circ} \mathrm{C}$ ).

Fig. 4: Pre-mix for Carrot Dessert

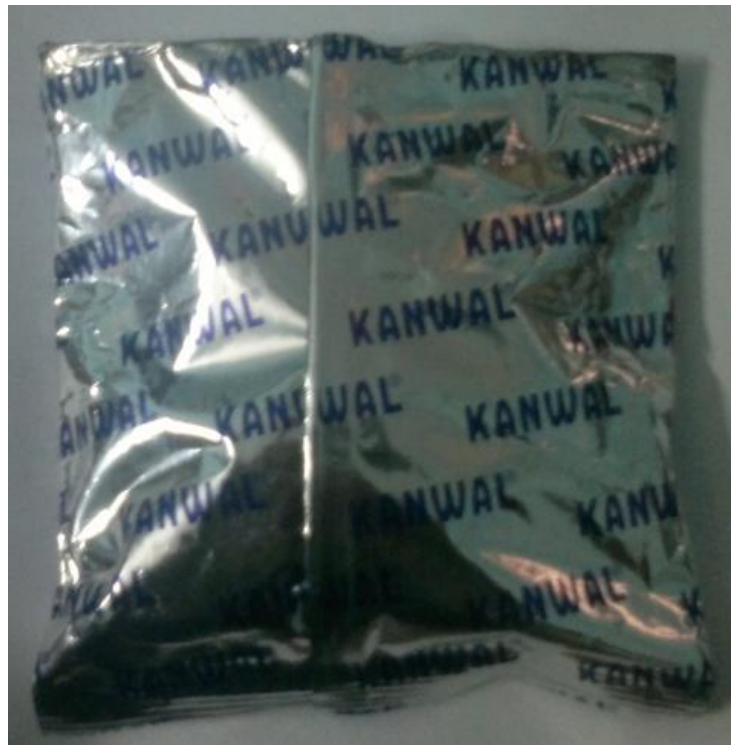

Fig. 5: Package design of Premix 


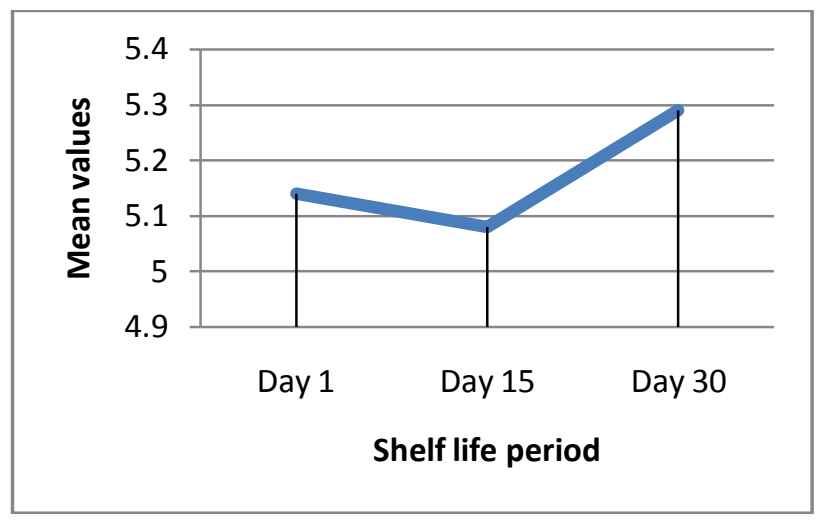

Fig. 6: Mean pH of Premix

Tables:

Table 1: Proximate composition \% of dried carrots

\begin{tabular}{|c|c|c|c|}
\hline Analysis & Day1 & Day15 & Day30 \\
\hline Moisture & 7.61 & 7.46 & 8.33 \\
\hline Ash & 6.68 & 6.20 & 6.28 \\
\hline Fat & 1.51 & 1.50 & 1.50 \\
\hline Protein & 6.27 & 6.24 & 6.20 \\
\hline Carbohydrate & 77.93 & 78.60 & 77.69 \\
\hline
\end{tabular}

Table 2: Proximate composition in g of Premix/160g (Recipe 3)

\begin{tabular}{|c|c|c|c|c|}
\hline Recipe & Ash & Fat & Protein & Carbohydrate \\
\hline 1 & $6.79 \pm 0.30$ & $4.93 \pm 0.45$ & $19 \pm 0.60$ & $122 \pm 0.54$ \\
\hline
\end{tabular}

Table 3: Results of microbial tests for premix on day 1,15 , and 30 stored at $25^{\circ} \mathrm{C}$ which is expressed in cfu/g

\begin{tabular}{|c|c|c|c|}
\hline Microbial type & Day 1 & Day 15 & Day 30 \\
\hline Aerobic Plate Count & $2.70 \times 10^{2}$ & $3.20 \times 10^{2}$ & $4.30 \times 10^{2}$ \\
\hline Coliforms & $1.00 \times 1^{1}$ & $1.00 \times 10^{1}$ & $1.00 \times 10^{1}$ \\
\hline Yeast & $0.05 \times 10^{1}$ & $<1.00 \times 10^{1}$ & $<1.00 \times 10^{1}$ \\
\hline Moulds & $<1.00 \times 10^{1}$ & $<1.00 \times 10^{1}$ & $<1.00 \times 10^{1}$ \\
\hline
\end{tabular}

Table 4: Sensory scores of Carrot desert

\begin{tabular}{cccccc}
\hline S. No. & Color & Texture & Aroma & Taste & Rank \\
\hline Recipe 1 & $8.3 \pm 0.60^{\mathrm{e}}$ & $8.00 \pm 0.82^{\mathrm{c}}$ & $8.20 \pm 0.64^{\mathrm{d}}$ & $8.00 \pm 0.8 \mathrm{~b}^{\mathrm{c}}$ & $8.00 \pm 0.82^{\mathrm{c}}$ \\
Recipe 2 & $7.40 \pm 0.80^{\mathrm{a}}$ & $7.70 \pm 0.46^{\mathrm{b}}$ & $7.00 \pm 0.89^{\mathrm{a}}$ & $7.70 \pm 0.64^{\mathrm{ab}}$ & $7.30 \pm 0.64^{\mathrm{a}}$ \\
Recipe3 & $8.10 \pm 0.54^{\mathrm{d}}$ & $7.8 \pm 0.60^{\mathrm{b}}$ & $8.10 \pm 0.54^{\mathrm{d}}$ & $8.10 \pm 0.30^{\mathrm{c}}$ & $8.00 \pm 0.45 \mathrm{c}$ \\
Sample 4 & $8.00 \pm 0.82^{\mathrm{bc}}$ & $7.90 \pm 0.70^{\mathrm{c}}$ & $7.90 \pm 0.7^{\mathrm{c}}$ & $8.00 \pm 0.63^{\mathrm{b}}$ & $7.9 \pm 0.54^{\mathrm{c}}$ \\
\hline
\end{tabular}

a Mean value \pm standard deviation $(\mathrm{n}=10)$

bMean values marked with different superscripts in the same column are significantly different- Duncan $(\mathrm{p} \leq$ $0.05)$.

\section{Conclusion}

Carrot desert supplemented with dried fruits was successfully produced, and is now available in the market under the trade name "Kunwal Carrot Dessert" (Marketted and Distributed by Kunwal Foods and Spices). HDPE as packaging material with aluminium film on inner side acted as an excellent barrier for moisture, flavour, micro-organisms. The use of coconut powder in the desert gained an edge over the other products available in the market.

\section{Acknowledgements}

We thankfully acknowledge Mr. Mohammad Amin Chadinoo the founder of Kanwal Group of Industries for his assistance and support and allowing us to work on the project.We would like to express our sincere gratitude to our co-supervisor Ms.NazimaNisar, Director (Administrations \& Quality Control) of 
Kanwal Group of Industries for her time, effort and guidance throughout our research.It gives us immense and unfathomable pleasure to submit our record under the guidance of our thesis advisor, Dr. DeebaShamimJairajpuri Assistant Professor, Department of Food Technology, Jamia Hamdard.

\section{References}

[1]. Grishin, M. A. andMariupolskaya, L. D. (1973). Investigations into the drying of carrots and onions for the manufacture of preserved vegetable snacks.Izvestiya-Vysshikh-Uchebnykh-Zavedenii,-Pishchevaya-Tekhnologiya, 6, 151-154.

[2]. 10. Basantpure, D., Kumbhar, B.K. and Awashthi, P. (2003). Optimization of levels of ingredients and drying air temperature in development of dehydrated carrot halwa using response surface methodology. Journal of Food Science and Technology, 40, 40-44.

[3]. 11. Kruszelnicki K. S. Carrots \& Night Vision.Great Moments in Science. ABC

[4]. Mulet, Berna, and Rossello, (1989). Drying of carrots I Drying models.Drying Technology, 7(3), $537-557$.

[5]. Machewad, G. M., Kulkarni, D. N., Pawar, V. D. andSurve, V. D. (2003). Studies on dehydration of carrot (Daucuscarota L.). Journal of Food Science and Technology, 40(4), 406-408.

[6]. Machewad, G. M., Kulkarni, D. N., Pawar, V. D. andSurve, V. D. (2003). Studies on dehydration of carrot (Daucuscarota L.). Journal of Food Science and Technology, 40(4), 406-408.

[7]. Midilli, A., Kucuk, H., Yapar, Z. A. (2002). New model for single-layer drying.Drying Technology, 20(7), $1503-1513$.

[8]. Pazarincevic T. J. andBaras, J. (1970). Effects of drying processes on transbetacarotene content of dehydrated carrots. Hrana-iIshrana, 11(7/8), 325-330.

[9]. Panchariya, P. C., Popovic, D. and Sharma, A. L. (2002). Thin-layer modelling of black tea drying process. Journal of Food Engineering, 52, 349-357.

[10]. Reyes, A., Alvarez, P. I. and Marquardt, F. H. (2002). Drying of carrots in a fluidized bed. I. Effects of drying conditions and modelling. Drying Technology, 20(7), 1463-1483. 